\title{
Interpretive U.S. Geological Survey Programs with Municipalities in Iowa
}
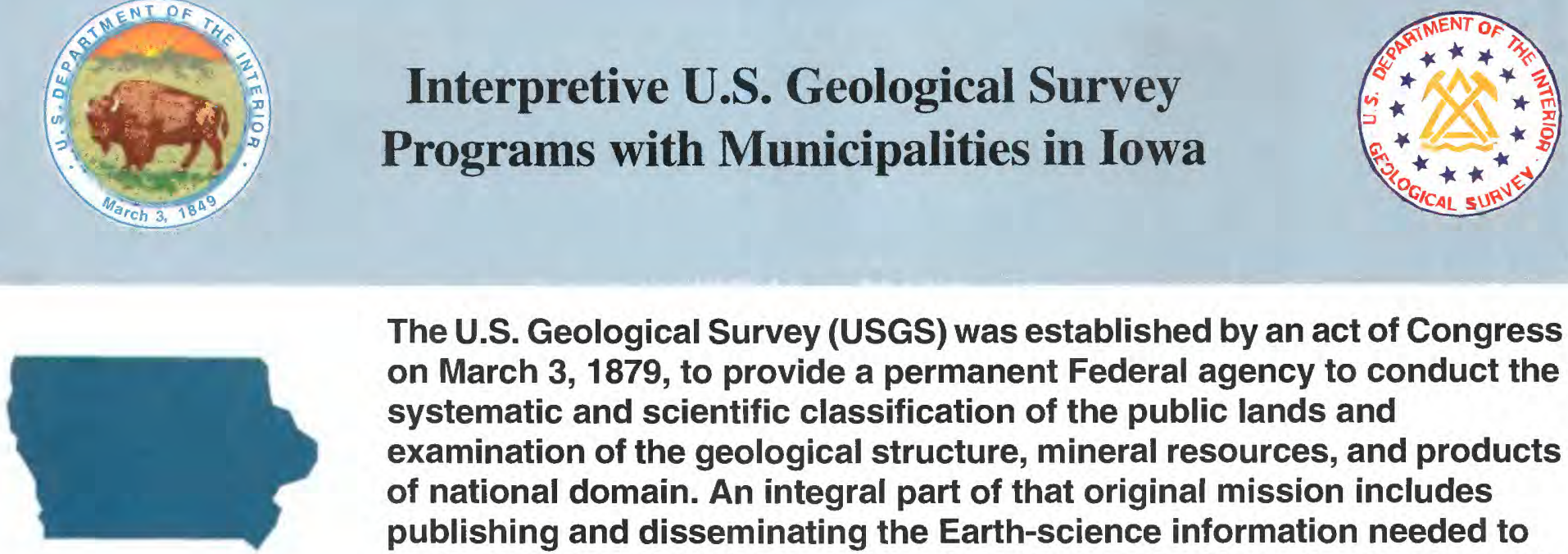

The U.S. Geological Survey (USGS) was established by an act of Congress on March 3,1879, to provide a permanent Federal agency to conduct the systematic and scientific classification of the public lands and examination of the geological structure, mineral resources, and products of national domain. An integral part of that original mission includes publishing and disseminating the Earth-science information needed to understand, to plan the use of, and to manage the Nation's energy, land, mineral, and water resources.

Since 1879 , the research and fact-finding role of the USGS has grown and been modified to meet the changing needs of the Nation it serves. As part of that evolution, the USGS has become the Federal government's largest Earth-science research agency, the Nation's largest civilian map-making agency, and the primary source of data on surface- and ground-water resources.

\section{Programs with Municipalities}

The USGS conducts cooperative data collection and interpretive studies with more than a dozen municipal governments in Iowa through the USGS Federal-State Cooperative Program. The Federal-State Cooperative Program, a partnership between the USGS and State and local agencies, provides a source of funding for information to support water-resources management and planning activities. Cooperators include municipal public works departments, naturalresource agencies, public health agencies, and more. Cooperative activities include water supply, groundwater quality and quantity, effects of agricultural chemicals, floods, droughts, and environmental protection. Results of individual studies can have application to other locations with similar problems. Federal

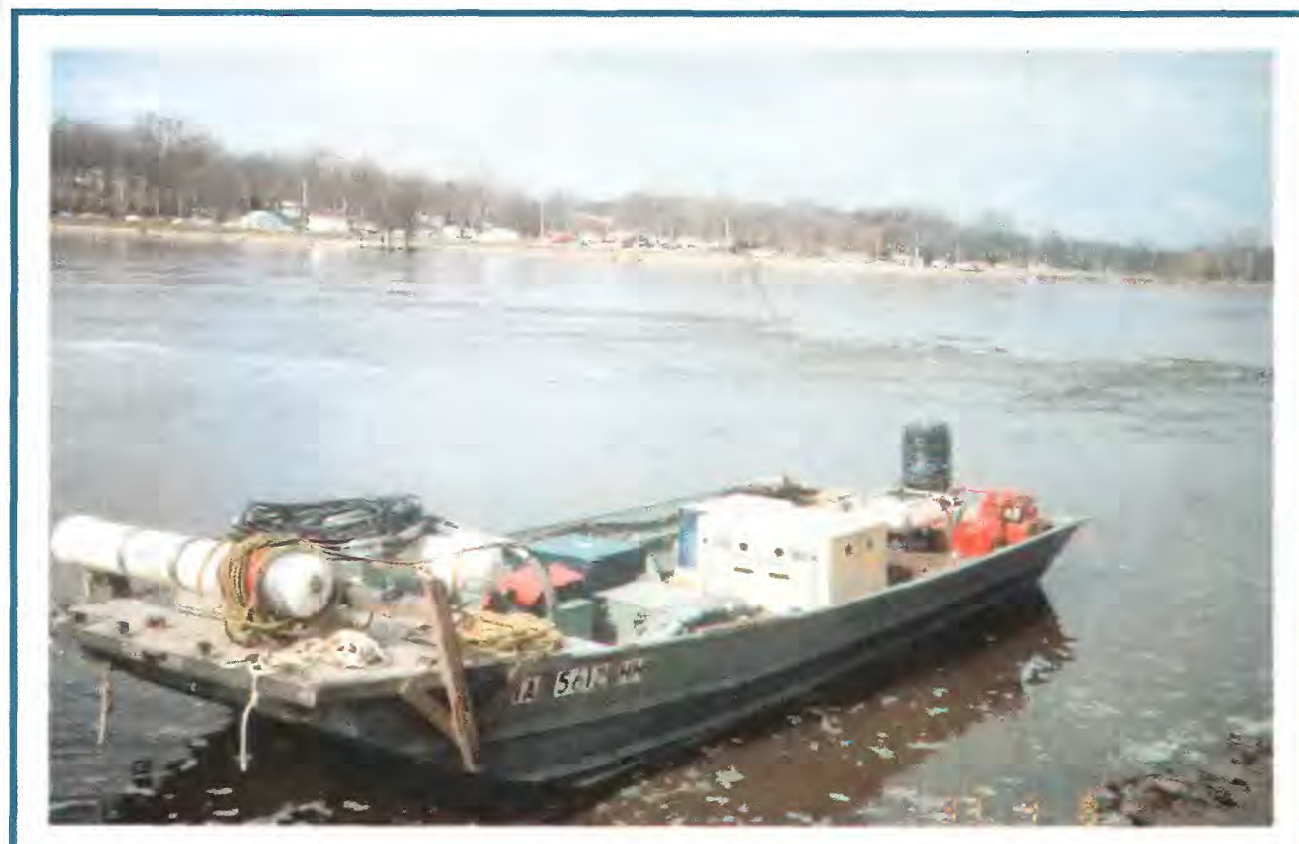

Boat with marine seismic equipment used for determining depth to bedrock on the Cedar River (Source: U.S. Geological Survey). matching funds are available through the Cooperative Program to provide up to 50:50 Federal/local match.

Examples of four interpretive studies with Iowa municipalities are described below.

\section{Cedar Rapids}

Cedar Rapids, Iowa, obtains its municipal water supply from shallow wells (less than 100 feet deep) completed in alluvial sand and gravel deposits along the Cedar River. Municipal water withdrawals averaged about 23 million gallons per day during 1990. During summers of below normal rainfall and greater than normal temperatures, withdrawals increase to more than 40 million 
gallons per day. The city currently is able to meet its demand for water, although during times of drought the system is stressed and changes in water quality have been observed. The USGS began a cooperative program with Cedar Rapids in 1992 to determine the maximum sustained yield of the alluvial aquifer, to identify possible threats to the quality of water in the aquifer, and to provide information useful for planning additional withdrawals to meet projected water demands and economic growth.

Activities of the USGS on this study have consisted of creating a map of the present alluvial well fields and identifying a variety of potential water-quality threats within a 2-mile distance of the supply wells. Surface geophysical techniques were used to determine the thickness of sand and gravel along the Cedar River from Cedar Rapids to Palo, Iowa. Information from this effort was used by the city to locate a new horizontal-collector municipal-supply well. Waterquality samples were collected to assist the city with determining the filtering efficiency of the sand and gravel in removing micro-

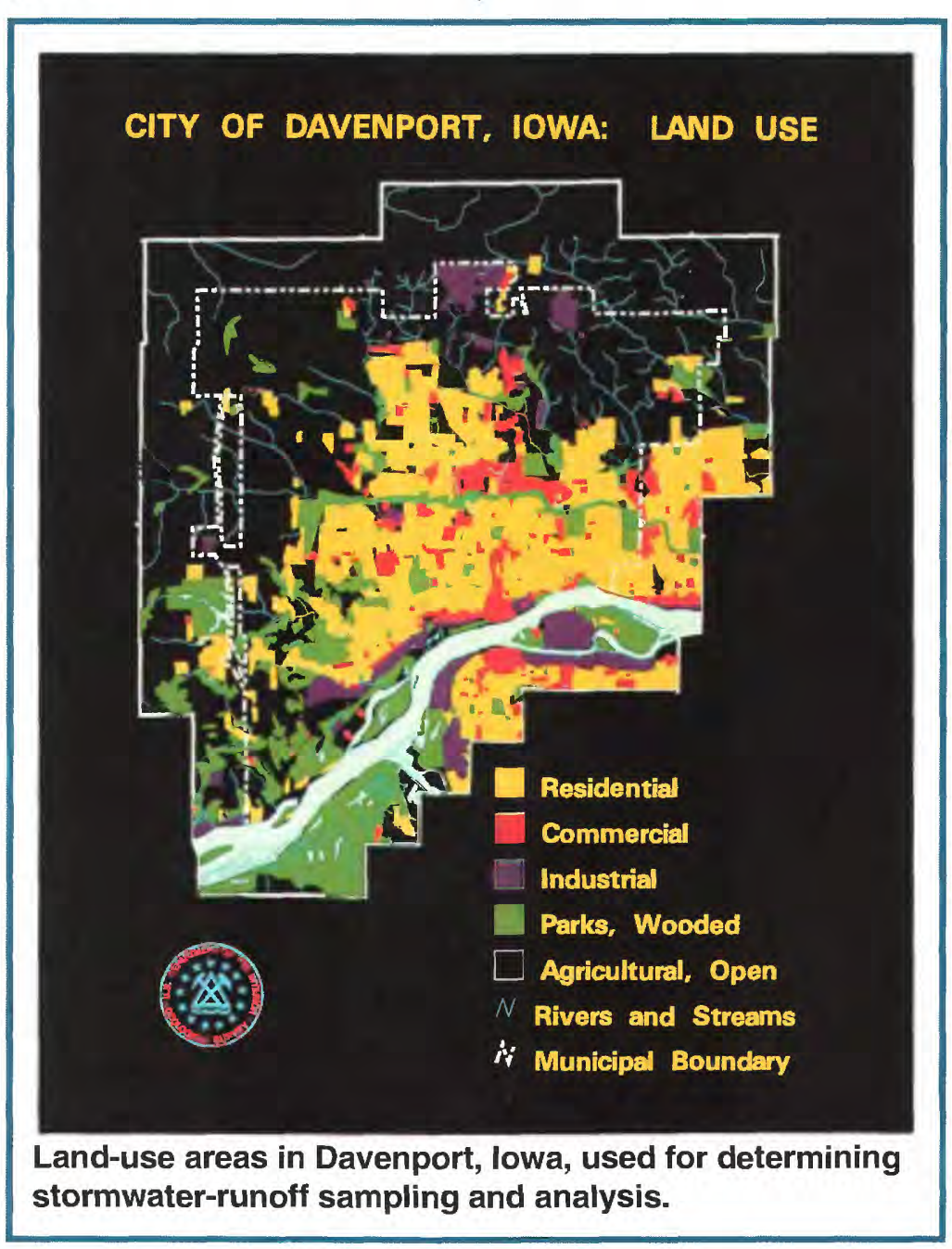

Discharge Elimination System (NPDES) because cumulative constituent loads associated with urban runoff can have substantial effects on the water quality of receiving streams. To develop a better understanding of these effects, the USGS began a cooperative program with the city of Davenport in 1991 to characterize the quantity and the quality of stormwater in streams and channels from areas within Davenport, Iowa.

The main objective of USGS activities was to determine the concentrations and annual loads of specific waterquality constituents in stormwater discharges from five types of land use in Davenport - residential, commercial, industrial, agricultural, and open vacant space. To accomplish this objective, a computerized map of the city was prepared to categorize the land use. From this map, five representative areas of specific land use were selected for monitoring of stormflow water quality. Stream-gaging and water-sampling stations were constructed on the creeks or ditches that drained these five small watershed areas. Upon

organisms contained in the Cedar River (Schulmeyer, 1995). Various ground-water flow models also are being constructed to assist in determining the source of water to the aquifer during periods of pumping.

\section{Davenport}

The U.S. Environmental Protection Agency (EPA), under Section 402(p) of the Water Quality Act of 1987, requires discharges of municipal stormwater systems from cities of population greater than 100,000 to be included in EPA's National Pollution activation of the stream-gaging stations, USGS personnel began monitoring weather conditions 24 hours per day, 7 days per week, in the Davenport area so that water-quality samples could be collected from rain storms that met the NPDES requirements for sampling. Chemical results were combined with streamflow data to determine the concentrations and loadings of specific water-quality constituents in runoff from each of the five land-use areas. An initial sampling was completed in 1992 (Schaap and Lucey, 1994) and a follow-up sampling was completed in 1994 (Schaap and Einhellig, 1996). 


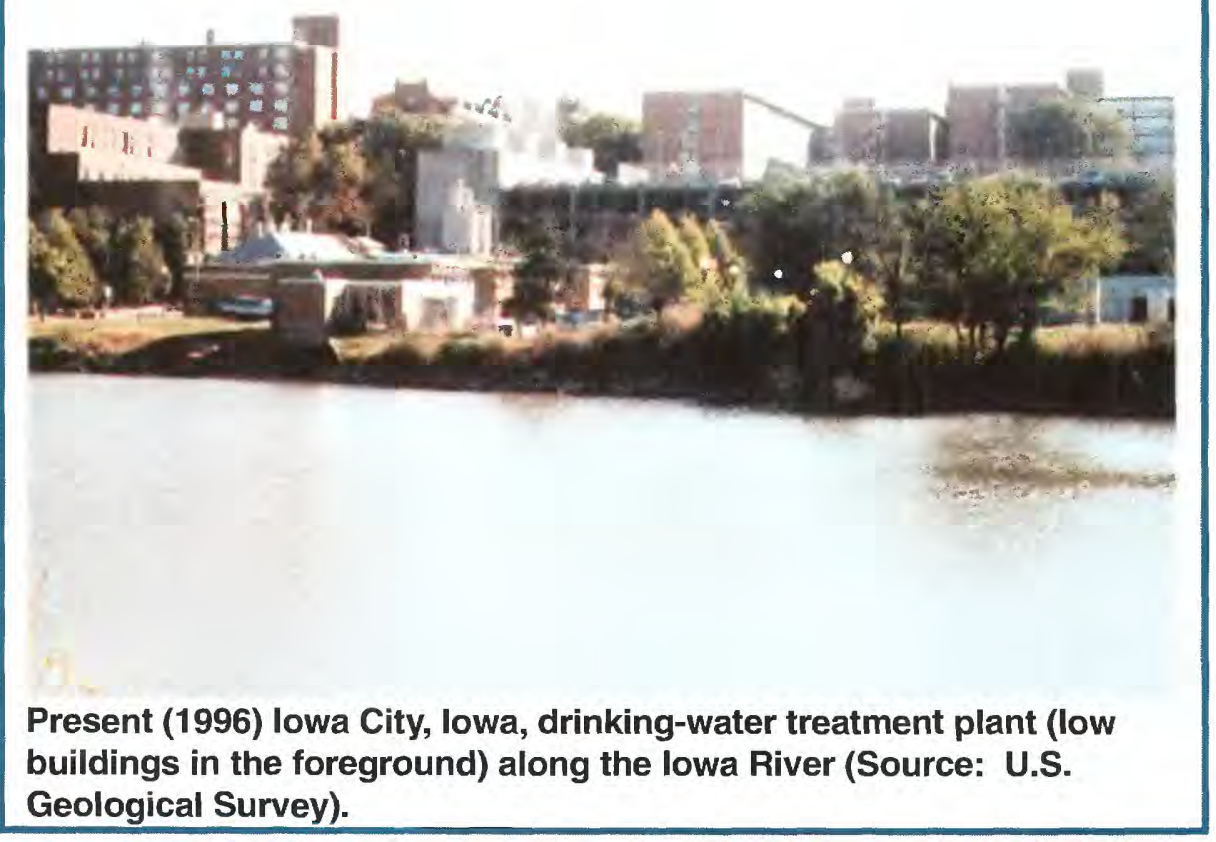

evaluate fluctuations in the Silurian aquifer water levels. The collected information is being stored and made available to the public and governmental agencies to increase the understanding of the effects and timing of withdrawals from the aquifers on water levels in the area.

\section{Muscatine}

Muscatine Power and Water (MPW) obtains water for public supply and other uses from an extensive alluvial sand and gravel deposit along the Mississippi River south of Muscatine, Iowa, known as the Muscatine Island alluvial aquifer. The aquifer covers about 50 square miles and varies in thickness from 40 to 150 feet.

\section{lowa City}

The major population centers in Johnson County utilize various groundwater sources to provide public-water supplies. Recently, Iowa City has begun efforts to locate and utilize an increased amount of ground water for its public supply. The aquifer in Silurian-age rocks in Johnson County currently (1996) is a water supply for various users including: the municipalities of Coralville, Iowa City, North Liberty, and Tiffin; the University of Iowa; a variety of rural and suburban residential communities to the north of Iowa City; and several self-supplied commercial and industrial businesses. Some of the users in the vicinity of the new watertreatment plant and new supply wells have expressed concern regarding the effects of future municipal withdrawals on their individual wells.

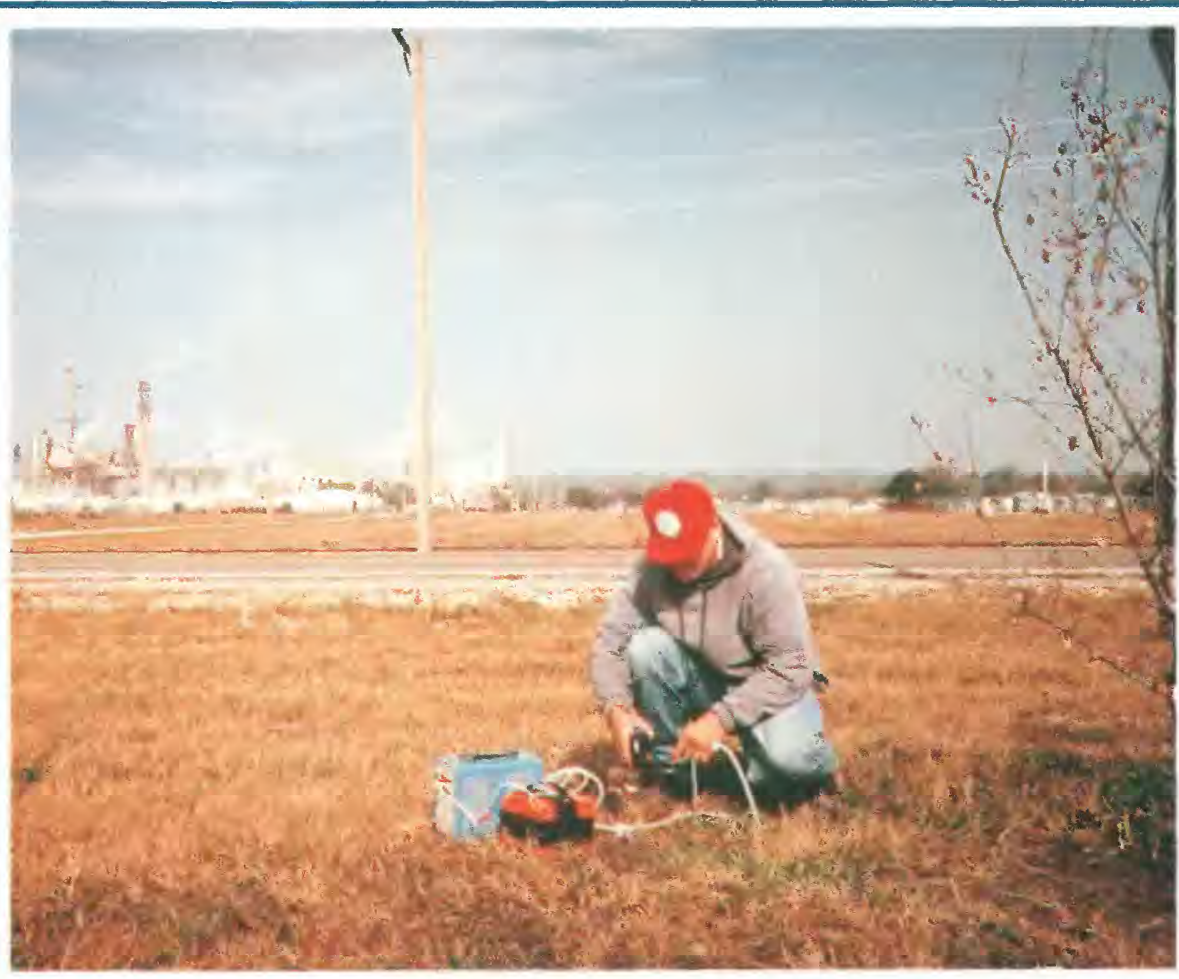

Sampling of ground water near Muscatine, lowa, municipal well field (Source: U.S. Geological Survey).
The USGS, in cooperation with Iowa City, is collecting water-level information from the Silurian and Jordan aquifers in the Iowa City/Coralville area to determine background hydrologic conditions before Iowa City begins to withdraw additional water. Additional information on the location and amounts of Silurian aquifer use in the area is being obtained to
Ground-water withdrawals have increased considerably since the last hydrogeologic study was completed in 1977 (Hansen and Steinhilber, 1977). Withdrawals for municipal, industrial, and irrigation use have increased and there has been a gradual deterioration in water quality. The USGS began a cooperative investigation with MPW in 1992 to determine the sources and quality of 
water in the alluvial aquifer and to document changes in water quality that have occurred.

To accomplish the objectives of the program, USGS personnel evaluated data collected by MPW and designed a new observation well network of more than 80 wells to provide information on geology, water levels, and water quality. Samples were collected every 3 months from 20 wells, the Mississippi River, and Muscatine Slough. A digital groundwater-flow model of the study area was constructed to help evaluate the flow of water in the aquifer. Results of the study are published in Lucey and others (1995).

\section{References Cited}

Hansen, R.E. and Steinhilber, W.L., 1977, Geohydrology of Muscatine Island, Muscatine County, Iowa: Iowa Geological Survey Water-Supply Bulletin No. 11, 60 p.

Lucey, K.J., Kuzniar, R.L., and Caldwell, J.P., 1995, Hydrogeology and water quality of the Mississippi River alluvium near Muscatine, Iowa, June 1992 through June 1994: U.S. Geological Survey Water-Resources Investigations Report 95 4049, 74 p.

Schaap, B.D. and Einhellig, R.F., 1996, Water-quality data of stormwater runoff from Davenport, Iowa, 1992 and 1994: U.S. Geological Survey Open-File Report 95-759, 46 p.

Schaap, B.D. and Lucey, K.J., 1994, Selected nutrients in stormwater runoff from Davenport, Iowa, 1992: U.S. Geological Survey WaterResources Investigations Report 94-4130, 29 p.

Schulmeyer, P.M., 1995, Effect of the Cedar River on the quality of the ground-water supply for Cedar Rapids, Iowa: U.S. Geological Survey Water-Resources Investigations Report 944211, 68 p.

\section{USGS representative}

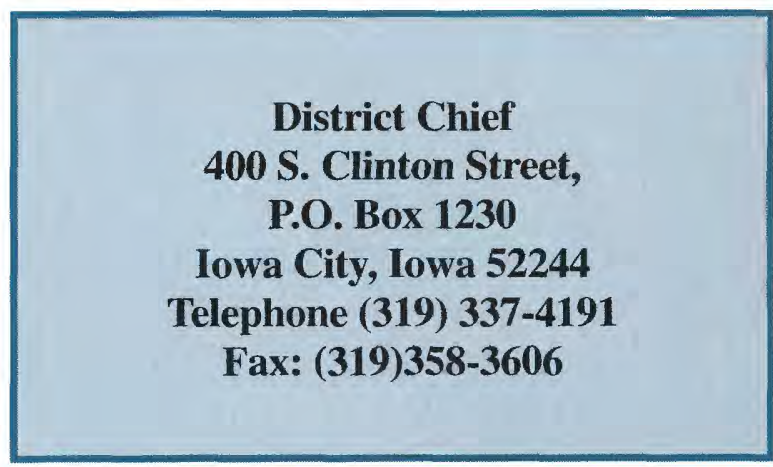

\section{Additional earth science information can be found by accessing the USGS lowa Home Page on the World Wide Web at http://wwwdiaiwc.cr.usgs.gov}

\author{
For more information on \\ all USGS reports and products \\ (including maps, images, \\ and computerized data), call \\ 1-800-USA-MAPS
}

The USGS provides maps, reports, and information to help others meet their needs to manage, develop, and protect America's water, energy, mineral, and land resources. The USGS helps find natural resources needed to build tomorrow and to supply scientific information needed to help minimize or mitigate the effects of natural hazards and environmental damage caused by human activities. The results of USGS efforts touch the daily lives of almost every American.

\section{U.S. Geological Survey Fact Sheet FS-201-96}

